\title{
HOMENAGEM À CÉLIO NOGUEIRA
}

\author{
João BATISTA NETO \\ Prof. Adjunto/Mestre de Cirurgia do Aparelho Digestivo da Faculdade de \\ Medicina da Universidade Federal de Alagoas, Maceió, AL, Brasil
}

$\mathrm{P}$ ara ser grande, sê inteiro. Põe quanto és no mínimo que fazes; assim, em cada lago a lua toda brilha, porque alta vive". (Odes de Ricardo Reis - Fernando Pessoa, 14/02/1933).

Assim como a lua, Célio Nogueira iluminou seus alunos de graduação e os pós-graduandos - mestres e doutores -, do seu lugar no panteão dos ícones da cirurgia nacional. Espraiava sobre todos estímulo, generosidade e esperança desmedidas.

Defendeu teses de Livre-docência em Clínica Cirúrgica e Técnica Operatória durante a vida acadêmica. Foi bolsista em França com Mallet-Guy, aluno e professor da faculdade de medicina da UFMG, da turma de 55. Escreveu inúmeros capítulos em livros e 87 trabalhos científicos.
Esteve sempre na fronteira da cirurgia; realizou o primeiro transplante de pâncreas com sucesso no Brasil - órgão em que tornou-se especialista - e a segunda colecistectomia laparoscópica; adotou logo a cirurgia bariátrica. Pertenceu à Academia Mineira de Medicina e se fez presente na fundação do CBCD e da SOBRACIL, vislumbrando novos tempos, além de assíduo colaborador do CBC.

Pontificou na Santa Casa de Belo Horizonte e também na pós-graduação da Escola de Ciências Médicas das Minas Gerais. Programou sua retirada dos palcos dos congressos médicos e da vida cirúrgica em 2002, sem conhecer o definhar.

Nascido em 1932, teve seu instante derradeiro em 17 de fevereiro de 2010. 